\title{
PELAYANAN PASTORAL BAGI ISTRI YANG BERDUKA DAN SIGNIFIKANSINYA TERHADAP PROSES PENEMUAN MAKNA HIDUP JEMAAT GEREJA KRISTEN JAWA KISMOREJO KARANGANYAR
}

\author{
Rini Wulandari
}

\section{PENDAHULUAN}

Mengalami kehilangan bukanlah hal yang mudah untuk dilalui bagi sebagian orang. Apalagi jika kehilangan itu terjadi untuk selama-lamanya. Ada bekas luka yang ditinggalkan dan memerlukan pemulihan. Pada beberapa orang pemulihan itu membutuhkan waktu sangat lama, namun tidak demikian pada sebagian orang.

Dari semua kehilangan ternyata kematian menjadi penyebab terbesar karena membutuhkan waktu cukup lama bagi seseorang untuk sembuh dari kedukaan. Apalagi jika kematian itu terjadi secara tiba-tiba atau tidak disangka-sangka. Kematian karena kecelakaan atau kekerasan yang menyebabkan orang yang ditinggalkan tidak bisa melihat jasadnya lagi secara utuh tentu meninggalkan duka yang mendalam. Oleh sebab itu cara orang menanggapi kehilangan pun sangat bervariasi.

Apabila seseorang terus larut dalam kedukaannya, maka lamakelamaan hidupnya bisa menjadi runtuh. Seseorang bisa merasa tidak bermakna dan menjadi tidak berdaya lagi karena kepergian orang yang dicintai untuk selama-lamanya. Jika hal ini dibiarkan terus dan tidak ditangani secara dini, bisa menimbulkan gejala patologis yang memerlukan penanganan lebih serius. Oleh sebab itu, pelayanan atau pendampingan pastoral pasca pemakaman sangat diperlukan. Langkah ini penting karena orang-orang yang menderita kehilangan karena kematian memerlukan penopangan.

Sejauh ini pelayanan pastoral yang dilakukan kepada jemaat yang berduka di gereja yang penulis teliti, hanya diberikan pada waktu sebelum dan saat upacara pemakaman atau bila ada kebaktian penghiburan saja. Beberapa hari sesudah pemakaman tidak ada kunjungan rutin atau percakapan pastoral dari pihak gereja untuk menghibur atau membantu jemaat yang berduka keluar dari perasaan problematis yang muncul. Sedangkan jemaat memerlukan 
pendampingan tersebut meski dari beberapa informan yang diwawancarai belum sampai menunjukkan gejala yang mengarah kepada patologis.

Bertolak dari hal di atas, maka penulis terdorong untuk mengkaji lebih jauh tentang pelayanan pastoral bagi jemaat yang mengalami kedukaan karena kematian orang yang dicintai, dalam hal ini para istri yang ditinggal mati suaminya serta bagaimana pelayanan pastoral tersebut bisa menolong seseorang menemukan makna dalam kehidupannya.

\section{PEMBAHASAN \\ KEHILANGAN YANG MENYEBABKAN KEDUKAAN}

Kehilangan merupakan peristiwa yang menyedihkan bagi kebanyakan orang apalagi jika kehilangan itu terjadi untuk selama-lamanya. Peristiwa kehilangan tersebutdapat menyebabkan seseorang mengalami kedukaan bahkan juga stress yang akhirnya menyebabkan sakit secara fisik maupun psikologis.

Any loss can bring about grief: divorce, retirement from one's job, amputations, death of a pet or plant, departure of a child to college or athletic game, health failures, and even the loss of confidence or enthusiasm. ${ }^{1}$

Collins menyatakan bahwa kehilangan yang membawa kedukaan bisa dikarenakan perceraian, pensiun dari pekerjaan, diamputasi salah satu anggota badannya, kematian binatang atau tanaman piaraan, perpisahan karena anak masuk perguruan tinggi atau mengikuti pertandingan olahraga, gangguan kesehatan dan bahkan kehilangan rasa percaya diri dan gairah hidup. Namun demikian, kehilangan yang paling menyedihkan adalah ketika orang yang dicintai atau orang yang sangat berarti meninggal dunia.

Berikut ini daftar urutan kehilangan yang menyebabkan kedukaan bahkan stress pada seseorang menurut Thomas H. Holmes dan R.H. Rahe: ${ }^{2}$

\begin{tabular}{|c|l|c|}
\hline No & \multicolumn{1}{|c|}{ Peristiwa } & Nilai \\
\hline 1 & Kematian suami/istri & 100 \\
\hline 2 & Perceraian & 73 \\
\hline 3 & Kawin tetapi hidup terpisah dari suami/istri & 65 \\
\hline 4 & Penahanan di penjara atau lembaga lainnya & 63 \\
\hline 5 & Kematian seorang keluarga dekat & 63 \\
\hline
\end{tabular}

1 R. Collins, Gary, Christian Counseling: A Comprehensive Guide, (Texas: Word Books, 1980), 411.

2 Howard Clinebell, Tipe-tipeDasarPendampingandanKonseling Pastoral, (Yogyakarta:Kanisius, 2002), 245-247. 
Missio Ecclesiae, 8(1), April 2019, 17-44

\begin{tabular}{|c|c|c|}
\hline 6 & Luka-luka atau penyakit pribadi yang berat & 53 \\
\hline 7 & Perkawinan & 50 \\
\hline 8 & Dipecat dari pekerjaan & 47 \\
\hline 9 & Perdamaian dengan suami/istri dalam perkawinan & 45 \\
\hline 10 & Pensiun dari pekerjaan & 45 \\
\hline 11 & Perubahan besar dalam kesehatan anggota keluarga & 44 \\
\hline 12 & Kehamilan & 40 \\
\hline 13 & Kesulitan seksual & 39 \\
\hline 14 & $\begin{array}{l}\text { Mendapat anggota keluarga baru (kelahiran, anak angkat dan } \\
\text { orangtua yang menumpang) }\end{array}$ & 39 \\
\hline 15 & Penyesuaian dalam bisnis (penggabungan, kebangkrutan) & 39 \\
\hline 16 & Perubahan status financial & 38 \\
\hline 17 & Kematian seorang sahabat dekat & 37 \\
\hline 18 & Perubahan jurusan/macam pekerjaan & 36 \\
\hline 19 & Perubahan jumlah percekcokan dengan suami/istri & 35 \\
\hline 20 & Mengambil hipotek atau pinjaman uang & 31 \\
\hline 21 & Penutupan hipotek atau pinjaman & 30 \\
\hline 22 & Perubahan tanggung jawab dalam pekerjaan & 29 \\
\hline 23 & $\begin{array}{l}\text { Anak lelaki atau perempuan meninggalkan rumah (perkawinan, } \\
\text { masuk perguruan tinggi) }\end{array}$ & 29 \\
\hline 24 & Masalah dengan pihak mertua suami/istri & 29 \\
\hline 25 & Pencapaian pribadi yang luar biasa & 28 \\
\hline 26 & Istri mulai atau berhenti bekerja di luar rumah & 26 \\
\hline 27 & Mulai atau berhenti dari sekolah formal & 26 \\
\hline 28 & $\begin{array}{l}\text { Perubahan besar kondisi hidup (membangun rumah baru, membuat } \\
\text { model baru, lingkungan yang buruk) }\end{array}$ & 25 \\
\hline 29 & Perbaikan kebiasaan pribadi (pakaian, tata krama) & 23 \\
\hline 30 & Masalah dengan boss & 24 \\
\hline 31 & Perubahan besar dalam jam dan kondisi pekerjaan & 20 \\
\hline 32 & Perpindahan tempat tinggal & 20 \\
\hline 33 & Perpindahan ke sekolah baru & 20 \\
\hline 34 & Perubahan besar dalam kebiasaan rekreasi & 19 \\
\hline 35 & Perubahan aktivitas gerejawi & 19 \\
\hline 36 & Perubahan aktivitas social & 18 \\
\hline 37 & Mengambil hipotek untuk suatu pembelian kecil (mobil, TV,kulkas) & 17 \\
\hline 38 & Perubahan dalam kebiasaan tidur & 16 \\
\hline 39 & Perubahan jumlah pertemuan keluarga & 15 \\
\hline 40 & Perubahan kebiasaan makan & 15 \\
\hline 41 & Liburan & 13 \\
\hline
\end{tabular}




\begin{tabular}{|l|l|c|}
\hline 42 & Hari Natal & 12 \\
\hline 43 & Pelanggaran hukum (peraturan lalu lintas) & 11 \\
\hline
\end{tabular}

Menurut skala Holmes-Rahe di ataskematian menduduki peringkat teratas penyebab stress maupun kedukaan. Kematian menjadi penyebab terbesar karena membutuhkan waktu cukup lama bagi seseorang untuk sembuh dari kedukaan. Apalagi jika kematian itu terjadi secara tiba-tiba,misalkan karena kecelakaan atau kekerasan yang menyebabkan orang yang ditinggalkan tidak bisa melihat jasadnya lagi secara utuh. Julianto menuliskan tentang sakitnya kematian di dalam artikelnya bahwa kematian memang menyakitkan, terutama bagi yang ditinggalkan. Apalagi selama hidup ada hubungan batin atau kedekatan mendalam dengan yang dipanggil Tuhan. Sakit rasanya. ${ }^{3}$

Manusia memang tidak bisa menduga datangnya kematian. Kematian yang tiba-tiba, tidak disangka-sangka, atau kematian karena kekerasan biasanya diikuti oleh dukacita yang lebih panjang dan sulit, daripada kematian secara perlahan-lahan. Howard mengatakan bahwa cara orang menanggapi kehilangan sangat bervariasi dan bergantung kepada sumber daya batin, kualitas dan lamanya hubungan, waktu terjadinya kehilangan, apakah kematian itu sudah diduga dan sifat dari kematian itu sendiri. Makin bergantung dan ambivalen (mendua) hubungan itu, makin rumit penyembuhannya. ${ }^{4}$

Seorang istri (EK) yang suaminya meninggal delapan bulan yang lalu mengatakan kepada penulis bahwa dia tidak percaya kalau suaminya dinyatakan sudah meninggal oleh dokter karena serangan jantung yang tidak diketahui sebelumnya. Dia berharap bahwa itu hanyalah mimpi. Kematian itu begitu cepat dan tidak disangka-sangka. Ketika dia menyadari bahwa kematian itu bukanlah mimpi dia merasakan kehilangan yang hebat, sakit, perasaan menyesal bahkan perasaan bersalah yang dalam kepada almarhum. ${ }^{5}$ Pasangan ini sudah menikah selama hampir 8 tahun dan belum dikaruniai anak. Peristiwa kematian suaminya semakin memukul dirinya karena dia merasa akan sendirian. Apalagi dua tahun sebelumnya ibu EK juga meninggal. Ibu EK kini harus berjuang sendiri untuk urusan-urusan rumah tangga yang belum selesai. Saat EK harus berhadapan dengan tugas pekerjaan laki-laki dia merasa sedih karena biasanya sang suami yang menangani tetapi sekarang dia harus kerjakan sendiri.

Selain ibu EK, ibu (SH) yang suaminya meninggal dua tahun yang lalu juga menceritakan kepada penulis tentang kedukaannya karena kematian sang

3 http://kesehatan.kompasiana.com/kejiwaan/2012/04/08/sakitnya-kematian

4 Howard Clinebell, Tipe-tipe Dasar Pendampingan dan Konseling Pastoral, (Yogyakarta:Kanisius, 2002), 291.

5 Klien EK yang ditinggal suaminya meninggal 8 bulan yang lalu. 
suami. Berbeda dengan EK yang suaminya meninggal secara tiba-tiba, suami SH sudah bertahun-tahun sakit diabetes dan darah tinggi. SH sering mendampingi sang suami ke Rumah Sakit atau dokter untuk memeriksakan penyakitnya. Ketika kematian itu menjemput, SH juga merasakan kehilangan dan kesedihan sekalipun dia menyadari bahwa suaminya sudah tidak bisa ditolong lagi karena penyakitnya yang makin parah. ${ }^{6}$

Memang benar bahwa kematian seorang yang menderita sakit cukup lama akan memberi dampak berbeda dengan kematian yang sifatnya tiba-tiba. Beberapafaktorseperti kedekatan hubungan, waktu atau sifat kematian dan usia dari orang yang mati tersebut masing-masing dapat mempengaruhi reaksi seseorang terhadap kematian. Olehsebabituanggota keluarga yang ditinggalkan mestinya mendapat pertolongan yang tepat supaya rasa duka yang dialami dapat teratasi dengan baik.

Orang-orang yang menanggung kedukaan membutuhkan waktu untuk dapat menyesuaikan diri dengan keadaan yang baru dan ini tidak bisa terjadi begitu saja. Mengenai hal ini Abineno mengatakan bahwa ia harus aktif. Ia harus melakukan sesuatu. Dalam arti ia harus berusaha untuk mencernakan kehilangan itu. Ia harus turut bekerja dalam proses kedukaannya, sehingga ia akhirnya dapat menerima situasi baru tanpa orang yang ia cintai. ${ }^{7}$ Pelayanan atau pendampingan pastoral pasca pemakaman bisa menjadi salah satu cara untuk menolong seseorang keluar dari kedukaannya. Langkah ini penting karena orang-orang yang menderita kehilangan karena kematian memerlukan penopangan.

\section{$\underline{\text { Hakikat Pelayanan Pastoral }}$}

Pelayanan pastoral pada dasarnya merupakan pelayanan gereja yang mencerminkan pemeliharaan Allah terhadap ciptaan-Nya, secara khusus terhadap manusia. Pemeliharaan ini, di dalam Alkitab, digambarkan seperti pemeliharaan yang dilakukan gembala terhadap domba-dombanya. Menurut John Patton, istilah "pastoral" menunjuk pada sikap yang memelihara (care) dan mempedulikan (concern). ${ }^{8}$

Istilah pastoral ini berasal dari kata "pastor" dalam Bahasa Latin atau dalam Bahasa Yunani disebut "poimen", yang artinya "gembala". 9 Dalam kehidupan gerejawi, tugas pastoral ini biasanya diserahkan kepada pendeta

6 Klien SH yang suaminya meninggal 2 tahun yang lalu.

7 J.L.Ch. Abineno, Pelayanan Pastoral Kepada Orang Berduka, Jakarta: BPK Gunung Mulia, 1991, hal.5

8 John Patton, From Ministry to Theology-Pastoral Action and Reflection (Nashville:Abingdon Press), 1990, 65.

9 Aart Van Beek, Pendampingan Pastoral, Jakarta:BPK Gumung Mulia, 2007, 10. 
yang menjadi gembala bagi jemaat. Van beek menjelaskan lebih lanjut bahwa pengistilahan ini dihubungkan dengan diri Yesus Kristus dan karya-Nya sebagai "Pastor Sejati" atau "Gembala Yang Baik" (Yoh. 10). Ungkapan ini mengacu pada pelayanan Yesus yang tanpa pamrih, bersedia memberikan pertolongan dan pengasuhan terhadap para pengikut-Nya, bahkan rela mengorbankan nyawa-Nya. ${ }^{10}$

Berkaitan dengan pelayanan pastoral, Aart Van Beek lebih suka menggunakan istilah pendampingan pastoral. Istilah pendampingan berasal dari kata kerja "mendampingi". Mendampingi merupakan suatu kegiatan menolong orang lain yang karena suatu sebab perlu didampingi. Orang yang melakukan kegiatan "mendampingi" disebut sebagai "pendamping". Keduanya bersifat sejajar dan memiliki relasi timbal balik. Dalam hubungan antara pendamping dan yang didampingi memang tampaknya pendamping mempunyai fasilitas yang lebih dari orang yang didampingi. Tentu saja haruslah orang yang lebih sehat, memiliki ketrampilan atau skill dan lain sebagainya. ${ }^{11}$

Dengan demikian istilah pendampingan di sini, memiliki arti kegiatan kemitraan, bahu-membahu, menemani, membagi/ berbagi dengan tujuan saling menumbuhkan dan mengukuhkan. ${ }^{12}$ Pendampingan ini haruslah dilakukan secara holistik atau menyeluruh baik fisik, mental, sosial dan spiritual. Bukan hanya berfokus pada problem atau gejalanya saja sehingga orang yang didampingi bisa ditolong secara utuh.

Dalam kaitannya dengan kata "counselling" masih terdapat banyak pandangan yang berbeda-beda. Jika kata tersebut diterjemahkan ke dalam Bahasa Indonesia sebagai kata "pendampingan" maka akan menimbulkan arti sempit. Kata "counselling" diambil dari kata "counsellor" yang artinya penasehat. Sehingga istilah "counselling" pada awalnya memiliki arti lebih kepada "pemberian nasehat atau bimbingan". Sedangkan kata "pendampingan atau pelayanan" mempunyai aspek yang lebih luas yang bisa meliputi juga pemberian nasehat dan bimbingan. Jadi konseling itu merupakan salah satu bentuk dari pendampingan atau pelayanan pastoral.

Gintings dalam bukunya menjelaskan bahwa istilah konseling yang artinya penasehat, sudah digunakan dalam Perjanjian Lama, misalnya dalam 1 Tawarikh 27:32 dengan istilah soferim yang diterjemahkan dalam Bahasa Inggris counsellor artinya penasehat. ${ }^{13}$ Sedangkan dalam Perjanjian Baru istilah counselor paling sering muncul dalam hubungan dengan Roh Kudus

10 Ibid.

11 Aart Van Beek, Pendampingan Pastoral, Jakarta:BPK Gumung Mulia, 2007, 9-10.

12 Ibid, 9.

13 E.P. Gintings, Konseling Pastoral Terhadap Masalah Umum Kehidupan, Bandung: Jurnal Info Media, 2009, 9. 
(Yunani =parakletos); dalam Bahasa Indonesia diterjemahkan sebagai penghibur, penasehat dan penolong. ${ }^{14}$

Berangkat dari istilah-istilah tersebut di atas, maka sikap pastoral haruslah mewarnai semua sendi-sendi pelayanan orang percaya oleh karena mereka sudah digembalakan lebih dulu oleh Allah. Seorang gembala yang baik tentu akan merawat, memperhatikan, dan memelihara kawanan dombadombanya. Demikian pula di dalam pelayanan pastoral yang harus kita ingat adalah menggembalakan domba-domba Allah (1 Petrus 5:2,3). Mengasuh dan merawat domba-domba yang terluka dan tercabik-cabik kehidupannya oleh karena krisis kehidupan yang mereka alami, menjadi tugas utama seorang pendamping atau pelayan pastoral.

Dalam menghadapi penderitaan atau krisis kehidupannya tersebut dan dalam menemukan jawaban tentang tujuan hidupnya, tiap orang memiliki peluang untuk memilih yaitu memaknai penderitaan dalam hidupnya dari segi positif atau tidak memaknainya dengan memilih kehidupan yang hampa. Orang-orang yang menemukan arti hidup melalui penderitaan atau krisis yang dihadapi akan mempengaruhi kedalaman tujuan hidupnya dan juga pemulihan yang mengubah hidupnya. ${ }^{15}$ Karena itulah pelayanan pastoral diperlukan guna menopang orang-orang yang sedang menderita.

Salah satu cara untuk menolong orang yang berduka adalah melalui suatu terapi yang dikenal dengan istilah konseling kedukaan. Konseling kedukaan bertujuan membantu seseorang mengatasi kedukaan dan kesedihan yang diakibatkan oleh kematian orang yang dikasihi atau berkaitan dengan masalah kehidupan yang menimbulkan perasaan duka seperti misalnya perceraian.

Grief counseling is a form of psychotherapy that aims to help people cope with grief and mourning following the death of loved ones, or with major life changes that trigger feelings of grief (e.g., divorce) $)^{16}$.

Melalui konseling ini seseorang difasilitasi untuk mampu mengungkapkan emosi-emosi negatif dan pikiran-pikiran berkaitan dengan kehilangan yang dialaminya. Emosi tersebut bisa berupa perasaan cemas, marah, bersalah, sedih, kesepian, ingin menyendiri, bingung atau bahkan hampa. Maka jelaslah, bahwa seorang yang berduka sangat membutuhkan pendampingan, pemberdayaan, dan juga konseling bagi permasalahan mereka sehari-hari.

14 E.P. Gintings, Gembala dan Konseling Pastoral, Yogyakarta: ANDI, 2001, 3.

15 Rumondang Panjaitan dalam Daniel Susanto, Sekilas tentang Pelayanan Pastoral di Indonesia, Jakarta:Majelis Jemaat GKI Menteng, 2008,160.

16 http://www.griefcounseling.com, 3 Januari 2015 pukul 22.00 wib 


\section{BentukPelayanan Pastoral Bagi Orang yang Berduka}

Pelayanan pastoral dapat mengambil berbagai bentuk baik itu berupa kunjungan rumah tangga, percakapan biasa, percakapan pastoral, atau pelayanan lewat surat dan telepon. Berikut ini bentuk-bentuk pelayanan pastoral yang biasa dilakukan oleh gereja-gereja.

\section{a. Percakapan biasa}

Percakapan biasamerupakan bentuk dasar pelayanan pastoral. Inisiatif percakapan ini berada dalam tangan jemaat dan anggota-anggotanya. Percakapan ini bisa menjadi awal pintu masuk untuk melakukan percakapan pastoral. Dengan jalan ini jemaat tidak akan merasa takut atau tertekan.

\section{b. Percakapan Pastoral}

Percakapan pastoral ini memiliki banyak segi psikologis dan teologis. Percakapan ini melibatkan tiga pihak yaitu pastor, anggota jemaat dan Firman Tuhan. Seorang pastor harus bisa menciptakan relasi yang baik dengan anggota jemaat sehingga dia akan merasa nyaman, aman dan tenang. Sikap empati dan mau mendengarkan jemaat menjadi syarat penting dalam percakapan pastoral.

\section{c. Kunjungan Rumah Tangga / Visitasi}

Kunjungan rumah tangga biasanya dilakukan oleh penatua-penatua dan diaken dalam sebuah gereja. Oleh sebab itu sebenarnya penting sekali untuk memperlengkapi dan membina para penatua dan diaken dengan pengetahuan teologis dan psikologis. Di satu sisi mereka akan memiliki pengetahuan tentang Alkitab secara benar dan di sisi lain mempunyai pemahaman tentang manusia secara utuh.

\section{d. Supporting Group}

Supporting Group (kelompok penopang) adalah kelompok yang terdiri dari orang-orang yang mempunyai komitmen untuk bertemu secara teratur dengan tujuan saling mempedulikan, saling mendengar dan saling berbagi pengalaman. $^{17}$

17 K. Hansen "Support Groups", Dictionary of Pastoral Care and Couseling, eds. Rodney J. Hunter et al. (Nashville: Abingdon Press, 1990), 1243. 


\section{Fungsi Pelayanan Pastoral}

Pelayanan pastoral kepadaistri yang berduka juga harus didasarkan pada fungsi-fungsi pelayanan pastoral. Fungsi pelayanan pastoral merupakan tujuan-tujuan operasional yang hendak dicapai dalam memberikan pertolongan kepada orang lain. Menurut William A. Clebsch dan Charles R. Jaekle, ada empat fungsi dasar pastoral yaitu: menyembuhkan (healing), menopang (sustaining), membimbing (guiding), dan mendamaikan (reconciling). Howard Clinebell menambahkan fungsi yang kelima yaitu memelihara (nurturing). ${ }^{18}$

Pertama, fungsi menyembuhkan (healing). Suatu fungsi pastoral yang terarah untuk mengatasi kerusakan yang dialami orang dengan memperbaiki orang itu menuju keutuhan dan membimbingnya ke arah kemajuan di luar kondisinya terdahulu. ${ }^{19}$ Dalam proses penyembuhan ini kita harus melihat bahwa manusia itu tidak hidup sendiri tetapi hidup dalam suatu kelompok sosial dan keluarga tertentu. Oleh sebab itu manusia harus dipandang secara menyeluruh atau holistik, baik fisik, sosial, psikis maupun spiritual.

Kedua, fungsi mendukung (sustaining). Fungsi ini diwujudkan dengan menolong orang yang sakit (terluka) agar dapat bertahan dan mengatasi suatu kejadian yang terjadi pada waktu yang lampau, dimana perbaikan atau penyembuhan atas penyakitnya tidak mungkin lagi diusahakan atau kemungkinannya sangat kecil sehingga tidak dapat diharapkan lagi. ${ }^{20}$ Menurut Clebsch dan Jaekle fungsi menopang ini terdiri dari empat tugas, yaitu: penjagaan (preservation), penghiburan (consolation), penguatan (consolidation), dan pemulihan (redemption). ${ }^{21}$

Sebagaimana ditegaskan oleh Hiltner bahwa fungsi menopang ini berkaitan dengan suatu situasi yang secara keseluruhan tidak dapat diubah atau sekurang-kurangnya tidak dapat diubah pada saat ini. ${ }^{22}$ Sehingga seringkali orang-orang yang ditopang dalam pelayanan pastoral mempertanyakan penyebab dari penderitaan yang mereka alami. Hal ini dapat dilakukan atau diterapkan kepada orang-orang yang sakit terminal, orang yang berduka karena kematian, korban bencana alam, korban kekerasan dan lain sebagainya. Mereka sangat membutuhkan pelayanan pastoral dalam bentuk penopangan.

Ketiga, fungsi membimbing (guiding). Fungsi membimbing digunakan untuk membantu orang yang berada dalam kebingungan dalam mengambil

18 Clebsch \& Jaekle dalam Daniel Susanto, Pelayanan Pastoral di Indonesia pada Masa Transisi, Jakarta:STT Jakarta, 2006, 29.

19 Clebsch \&Jaekle dalam Howard Clinebell, Op.Cit., 53

20 Clebsch \&Jaekle dalam Howard Clinebell, Op.Cit., 53

21 Clebsch \& Jaekle dalam Daniel Susanto, Pelayanan Pastoral di Indonesia...., 30

22 Seward Hiltner, Preface to Pastoral Theology (Nashville, Tennessee: Abingdon Press, 1958), 116. 
pilihan yang pasti (meyakinkan di antara berbagai pikiran dan tindakan alternatif/pilihan), pilihan yang dipandang mempengaruhi keadaan jiwa mereka sekarang dan pada waktu yang akan datang. ${ }^{23}$

Keempat, fungsi memulihkan (Reconciling). Fungsi ini merupakan usaha membangun kembali hubungan-hubungan yang rusak di antara manusia dan sesama manusia dan di antara manusia dengan Allah. ${ }^{24}$ Dasar pelayanan pendamaian sebenarnya terletak dalam karya pendamaian Kristus. Kristuslah yang telah mendamaikan manusia dengan Allah, manusia dengan sesamanya dan manusia dengan alam. Di dalam upaya pendamaian pengampunan memainkan peranan yang sangat penting. ${ }^{25}$ Seorang istri yang berduka perlu mendapatkan pendampingan guna mengatasi konflik-konflik yang mungkin masih ada baik itu dengan almarhum atau kerabat dekat. Sebab bagaimana pun tidak bisa dipungkiri bahwa sekarang ini banyak terjadi baik itu konflik sosial maupun konflik antar pribadi.

Kelima, fungsi memelihara atau mengasuh (nurturing). Fungsi ini memampukan orang untuk mengembangkan potensi-potensi yang diberikan Allah kepada mereka,di sepanjang perjalanan hidup mereka dengan segala lembah-lembah, puncak-puncak dan dataran-datarannya. ${ }^{26}$ Melalui pelayanan pastoral yang bersifat memelihara ini diharapkan potensi-potensi yang belum dikembangkan dalam diri individu dapat diupayakan secara maksimal.

\section{Dasar Alkitabiah Pelayanan Pastoral}

Pelayanan pastoral dengan Alkitab memiliki hubungan timbale balik. Di satu sisi pelayanan pastoral menghidupkan kebenaran Alkitabiah dengan membiarkan kebenaran tersebut dialami sendiri oleh klien, di sisi lain Alkitab member penerangan atau memperjelas dalam praktik pelayanan pastoral.

Berkaitan dengan alasan-alasan di atas, kita melihat dalam Alkitab bahwa tujuan kedatangan Yesus ialah supaya orang mempunyai hidup dan mempunyainya dalam segala kelimpahan (Yohanes 10:10). Hidup dalam segala kelimpahan adalah cara Alkitab untuk menyatakan kesehatan secara holistik atau utuh yang berpusat pada Roh Kudus.

Allah telah menciptakan manusia dalam keserupaan dengan diri-Nya, namun dosa telah merusaknya. Pribadi yang utuh dalam diri manusia telah dikacaubalaukan oleh dosa. Tentu saja ini menghambat seseorang untuk melihat bahkan mengembangkan hal-hal unik yang ada dalam dirinya.

\footnotetext{
23 Op.cit, 53

Ibid

25 Daniel Susanto, Pelayanan Pastoral di Indonesia pada Masa Transisi..., 32

26 Ibid, 53
} 
Disinilah peran pelayanan pastoral menjadi penting yaitu untuk mengembangkan keunikan kepribadian menuju keserupaan dengan Allah.

Tuhan Yesus juga menasihatkan dalam Yohanes 13:34 supaya kita saling mengasihi sama seperti Dia telah mengasihi kita. Kasih merupakan dasar di dalam kita melakukan pendampingan dan konseling pastoral. Tanpa kasih, sulit bagi kita untuk duduk diam mendengarkan keluhan atau permasalahan orang yang kita dampingi.

Demikian juga sikap menggembalakan merupakan sikap yang dituntut dari seorang pendamping atau konselor. Rasul Petrus di dalam suratnya 1 Petrus 5:2,3 mengatakan demikian: "Gembalakanlah kawanan domba Allah yang ada padamu jangan dengan paksa, tetapi dengan sukarela sesuai dengan kehendak Allah, dan jangan karena mau mencari keuntungan, tetapi dengan pengabdian diri. Janganlah kamu berbuat seolah-olah kamu mau memerintah atas mereka yang dipercayakan kepadamu, tetapi hendaklah kamu menjadi teladan bagi kawanan domba itu".

\section{$\underline{\text { Langkah-langkah Pelayanan Pastoral kepada Orang Berduka }}$}

Gary R. Collins menekankan tiga hal utama yang harus diperankan oleh pendeta dan jemaat di dalam melakukan pelayanan pastoral bagi orang yang berduka. Pertama, mereka harus menyampaikan penghiburan dari Alkitab. Alkitab melukiskan kematian sebagai sebuah kemenangan yang besar bagi orang percaya dan sesuatu yang harus disambut (Filipi 1:21). Melalui kematian dan kebangkitan-Nya Kristus telah mengalahkan kematian sehingga setiap orang percaya diyakinkan akan kehidupan kekal di dalam Tuhan (Yoh. 3:16;14:1-3; 1Kor.15:54-57; 1Tes.4:13-18). Tuhan Yesus juga menjanjikan penghiburan bagi mereka yang berdukacita (Mat. 5:4) dan Ia juga menjelaskan bahwa Roh Kudus adalah Penghibur (Yoh.14:26) yang akan selalu hadir di saat-saat berduka. Hanya Kristuslah yang memberikan damai yang sejati dan kita seharusnya mengingatkan seorang akan yang lain tentang hal ini di saat berdukacita. ${ }^{27}$

Kedua, pemimpin gereja dapat membantu di dalam persiapan pemakaman. Pendeta atau pelayan gereja dapat membantu keluarga yang berduka untuk membuat keputusan berkaitan dengan tipe dan harga peti, tempat pemakaman dan hal-hal lainnya. Dia juga dapat memimpin di dalam pujian yang menguatkan yang menyatakan penghiburan dari Kristus serta menolong orang yang berduka untuk menerima kenyataan kematian tersebut. ${ }^{28}$

27 Gary R. Collins, Effective Counseling, (Illinois:Published by Creation House, 1972), 149.

28 Ibid, 150 
Ketiga, pemimpin gereja seharusnya melakukan pembimbingan atau pendampingan selama masa penyesuaian kembali. Ketika pemakaman telah berakhir, bunga-bunga pun menjadi layu dan banyak keluarga yang pulang ke rumah mereka masing-masing, maka bulan-bulan selanjutnya sering diliputi rasa sepi dan menyakitkan. Pada saat-saat seperti inilah orang-orang Kristen harus mampu memberikan penghiburan dan perhatian kepada orang yang berduka. $^{29}$

Para gembala jemaat dan anggota jemaat bisa melakukan kunjungan rutin kepada orang yang berduka agar mereka tidak merasa ditinggalkan atau harus berjuang sendirian. Fakta yang seringkali terjadi adalah banyak anggota jemaat maupun pemimpin gereja ikut mengundurkan diri bersama dengan selesainya upacara penguburan. Sesudah itu mereka tidak lagi melakukan kunjungan karena dianggap rasa duka itu sudah berlalu atau akan berlalu setelah satu bulan kemudian.

Seorang yang berduka karena kehilangan orang yang dicintai memerlukan kebutuhan-kebutuhan khusus agar luka yang dialami tidak lagi menyakitkan. W.F. Rogers, seorang pendeta Rumah Sakit yang berpengalaman, telah mendaftarkan kebutuhan-kebutuhan tersebut sebagai berikut: ${ }^{30}$

1. Kebutuhan akan dukungan dari orang lain. Pada saat berdukacita, penting sekali untuk memiliki orang-orang di sekitar kita misalnya jemaat gereja yang bisa hadir dan mau mendengarkan atau berbagi.

2. Kebutuhan untuk bisa menerima kenyataan akan kehilangan tersebut. Pengetahuan intelektual seseorang akan kenyataan bahwa orang yang dicintainya telah mati berbeda dengan penerimaan emosionalnya. Orang yang berduka harus melewati proses yang menyakitkan dalam menerima kenyataan kehilangan itu. Proses ini bisa berlangsung berbulan-bulan dan ini mestinya dipahami oleh orang-orang yang ada disekitarnya.

3. Kebutuhan untuk menyatakan kesedihan. Pada waktu Tuhan Yesus tiba di rumah Maria dan Marta menghadiri kematian Lazarus, Yesus menangis bersama-sama mereka (Yoh. 11:35). Seorang gembala jemaat hendaknya juga tidak melarang jika seorang yang berduka harus mencurahkan perasaan-perasaannya. Hal ini merupakan bagian yang

$\begin{array}{ll}{ }^{29} & \text { Ibid } \\ & \text { Id. at. } 146-148\end{array}$ 
penting dalam kedukaan baik bagi orang percaya maupun orang tidak percaya.

4. Kebutuhan untuk mengungkapkan dengan kata-kata permusuhan dan rasa bersalah. Kata-kata yang penuh kemarahan bisa saja ditujukan kepada orang lain maupun Tuhan bahkan terkadang ada kemarahan terhadap orang yang sudah meninggal tersebut. Hal ini nampaknya tidak rasional namun sebenarnya reaksi tersebut merupakan ungkapan frustasi mereka. Ketika orang yang berduka menyadari bahwa ia marah dengan Tuhan maka seringkali muncul perasaan bersalah yang besar.

5. Kebutuhan untuk membangun hubungan yang baru. Orang yang berduka harus menemukan relasi-relasi yang baru. Menjalin relasi baru ini menjadi bagian yang penting guna menolong orang yang berduka sembuh dari kedukaannya.

Bertolak dari penjelasan di atas, maka pelayanan kepada orang yang berduka menjadi amat penting. Pelayanan ini tidak bisa jika hanya dilakukan dengan ketrampilan saja namun harus dengan keikhlasan, kepekaan dan kelembutan khusus, simpati dan empati. Billy Graham menambahkan bahwa kita perlu bergantung pada pimpinan Roh Kudus. Terlalu gampang dan banyak bicara, atau memberikan jawaban, adalah bertindak lancang. Ucapan-ucapan kita harus tulus dan bermakna, peka dan tepat dengan situasi tersebut, sebab hiburan sejati bagi orang yang berduka tergantung di mana sesungguhnya dia berada dalam proses dukanya. ${ }^{31}$

\section{Hakikat Kedukaan}

Pada bagian ini, Penulis juga mengemukakan hal-hal yang berhubungan dengan kedukaan, antara lain pengertian kedukaan, jenis-jenis kedukaan, tahap-tahap kedukaan, serta akibat kedukaan.

\section{$\underline{\text { Pengertian Kedukaan }}$}

Kedukaan seringkali diartikan sebagai penderitaan karena didalamnya seseorang mengalami kerugian. Kerugian ini bisa disebabkan faktor kehilangan sesuatu yang dicintai. Hal ini bukan hanya berkaitan dengan barang atau materi tetapi juga orang-orang yang dicintai seperti suami, istri, anak-anak

31 Billy Graham, Buku Pegangan Pelayanan, (Penerbit: Persekutuan Pembaca Alkitab), 55-59. 
atau orangtua. Guna memahami lebih jelas tentang kedukaan, maka terlebih dulu perlu dipahami pengertian kedukaan secara umum dan pengertian kedukaan menurut pandangan Alkitab.

\section{a. Kedukaan Menurut Pandangan Umum}

Istilah dukacita atau kedukaan dalam Kamus Besar Bahasa Indonesia berarti kesedihan atau kesusahan. Kata ini berarti menunjuk kepada keadaan dukacita yang dialami. ${ }^{32}$ Webster's Dictionary mendefinisikan kata grief atau kedukaan yaitu 1) deep and painful sorrow as that caused by someone's death. 2) something that causes such sorrow. ${ }^{33} \mathrm{Jadi}$ istilah grief (kedukaan) adalah keadaan dukacita yang mendalam dan menyakitkan sebagai reaksi karena kehilangan sesuatu yang penting dalam hidup seseorang. Kehilangan tersebut bisa karena kematian orang yang dicintainya.

Menurut Abineno, kedukaan lebih dari penderitaan: kedukaan bukan saja terbatas pada apa yang kita rasakan, kedukaan juga mencakup apa yang kita pikirkan, apa yang kita ingini atau kehendaki, malahan juga apa yang kita lakukan atau kerjakan. ${ }^{34}$ Lindemann menyebut proses untuk sembuh dari luka kedukaan ini sebagai grief work (kerja kedukaan). Proses grief work ini melibatkan tiga hal yaitu individu mencoba melepaskan ikatan dengan orang yang meninggalkan dirinya, individu menyesuaikan diri dengan keadaan yang baru tanpa orang yang dikasihi, dan individu mencoba membina hubungan yang baru dengan sesamanya. ${ }^{35}$

Pengalaman kedukaan bisa berdampak negatif dalam hidup seseorang. Kedukaan berdampak negatif bila orang yang mengalaminya menekan kedukaan tersebut dan tidak berjuang untuk menyelesaikannya sehingga menyerap habis energi dan kreativitasnya. Makin lama proses penyembuhannya maka makin besarlah akibat luka yang akan dialami. Seluruh dimensi kehidupannya baik fisik, emosi, pikiran, sosial maupun spiritual bisa menjadi lumpuh.

Kedukaan juga menimbulkan reaksi yang berbeda-beda dalam diri tiap orang. Secara khusus kedukaan akibat kematian dapat meninggalkan pengalaman pahit yang menyakitkan. Reaksi seseorang terhadap kedukaan karena kematian berbeda-beda: ada yang pasif (menyerah karena kematian

32 HasanAlwi, Kamus Besar Bahasa Indonesia, Jakarta: Pusat Pendidikan Nasional, 2001,278

33 David B. Guralnik, Webster's New World Dictionary. (California: California State Department of Education, 1967), 310.

34 J.L. Ch.Abineno, Pelayanan Pastoral Kepada Orang Yang Berduka, (Jakarta: BPK Gunung Mulia, 1991), 1.

35 E.P. Gintings, Konseling Pastoral Terhadap Masalah Umum Kehidupan, (Bandung: Jurnal Info Media, 2009), 135. 
atau kehilangan itu mereka lihat sebagai "kejadian yang dikehendaki oleh Allah"), ada yang agresif (mengeluh, memberontak, memprotes, karena tidak bisa menerima kematian atau kehilangan itu) dan ada pula yang depresif (tertekan karena mereka tidak mampu menanggung beban penderitaan yang disebabkan oleh kematian atau kehilangan itu). ${ }^{36}$ Oleh sebab itu, ketrampilan yang konstruktif untuk menanggulangi dampak kehilangan sangat dibutuhkan sehingga individu akan mengalami proses penyembuhan yang lebih cepat.

Satu hal yang perlu diketahui bahwa kedukaan merupakan suatu proses. Hal ini berarti bahwa kedukaan itu membutuhkan waktu sehingga seseorang bisa menyesuaikan diri dengan situasi yang baru. Dia harus berlatih hidup tanpa orang yang dicintai. Kedukaan membutuhkan aktivitas yang seringkali menyita tenaga atau energi. Namun demikian, pada titik tertentu kedukaan ini akan berhenti. Ia tidak akan berlangsung selama-lamanya .

\section{b. Kedukaan Menurut Pandangan Alkitab}

Ada beberapa istilah yang dipakai untuk menggambarkan dukacita atau kedukaan dalam Alkitab, baik dalam Perjanjian Lama maupun Perjanjian Baru. Berikut ini akan dijelaskan arti dari istilah-istilah kedukaan baik dalam Kitab Perjanjian Lama maupun Perjanjian Baru.

\section{c. Kedukaan dalam Perjanjian Lama}

Ada beberapa istilah dalam Perjanjian Lama yang dipakai untuk menunjukkan keadaan dukacita, antara lain:

1. Kata marar. Kata ini menjelaskan mengenai kepedihan hati. Pengertian kata ini dihubungkan dengan kesengsaraan bangsa Israel di Mesir (Kel. 1:14); marah oleh karena mengalami penderitaan dan Allah nampaknya tidak adil dalam memelihara seseorang dari keadilan (Ayub 7:11; 23:2); tangisan yang tidak dapat dikendalikan oleh kemandulan (1 Sam. 1:10); kesedihan karena keadaan hidup tidak dapat diubah (Ayub 9:18); kepedihan hati karena kematian anak yang dikasihi (Kej. 37:34; 1 Sam. 30:6; 2 Raj. 4:27; Zakh. 12:10). ${ }^{37}$

2. Kata yagon. Kata ini berbicara mengenai kedukaan karena menanggung penderitaan dan kesesakan. Kata ini biasa digunakan dalam konteks ratapan (Kej. 42:38; 44:31; Ayub 19:2; Maz. 31:10; 107:39; 116:3; Yer. 8:18; Rat. 1:4,5,12; 3:32,33; Yeh. 23:33). ${ }^{38}$

36 J.L. Ch.Abineno, Pelayanan Pastoral Kepada Orang Yang Berduka, (Jakarta: BPK Gunung Mulia, 1991), ix.

37 John E. Hartley, “marar”, Dictionary of Old Testament and Exegesis Vol. 2. Michigan: Zondervan Publishing House, 1997, 1110.

38 Rosemary Nixon, “yagon” Dictionary of Old Testament....., 396 
3. Kata ke'ebh. Kata ini menjelaskan keadaan dukacita karena penderitaan yang dialami oleh seseorang, secara pribadi (Yer. 15:18) maupun kelompok (Yes. 65:14). Hal ini bisa berarti penderitaan secara fisik (Kej. 34:25) dan penderitaan batin (hati: Amsal 14:13; Yes. 65:14). ${ }^{39}$

Dengan demikan, dukacita atau kedukaan dalam Perjanjian Lama tidak hanya mengarah kepada dukacita karena kematian seseorang, namun dukacita juga bisa disebabkan oleh peristiwa-peristiwa yang terjadi di sekitar yang menyebabkan seseorang menjadi sedih, gelisah, sengsara, sakit hati dan sebagainya.

\section{d. Kedukaan dalam Perjanjian Baru}

Dalam Perjanjian Baru ada beberapa istilah yang dipakai untuk menunjukkan keadaan dukacita. Beberapa kata yang dipakai untuk menunjukkan kedukaan itu antara lain:

1. Kata pentheo dalam Matius 5:4 diterjemahkan berdukacita, berkabung, meratap. Penggunaan kata dukacita ini dihubungkan dengan kematian seseorang yang dikasihi atau orang yang dekat. ${ }^{40}$ Kata pentheo dalam Septuaginta sering digunakan, yang menunjuk kepada keadaan dukacita yang diekspresikan dengan air mata, meratap dan berkabung di dalam upacara pemakaman (meratap bagi yang meninggal: Kejadian 23:2; Mark. $16: 10){ }^{41}$

2. Kata Lupe. Kata ini menunjuk kepada dukacita yang disebabkan oleh sakit secara fisik dan emosional, perasaan cemas, gentar, takut dan sebagainya. ${ }^{42}$ Yesus pernah mengalami ketakutan dan kegentaran sebelum kematian-Nya (Mat. 26:37-38). Namun dalam kegentaran-Nya, Dia berdoa dan berserah kepada Bapa-Nya.

\section{Jenis-jenis Kedukaan}

Perasaan duka dialami oleh seseorang ketika ia menyadari bahwa ada sesuatu yang hilang dari dirinya. Kedukaan tidak hanya berkaitan dengan

39 Rosemary Nixon, “yagon” Dictionary of Old Testament....., 396

40 Thomas McComiskey, "pentheo”, Dictionary of New Testament Theology Vol. 2. Michigan: Zondervan Publishing House, 1979,421.

41 H. Balz, Exegetical Dictionary of New Testament Vol. 3. Michigan: Wm. B. Eerdmans Publishing Company. 1991, 69. 2006), 13 .

42 Hadi P. Sahardjo, Konseling Krisis dan Terapi Singkat, (Bandung: Pioner Jaya, 
kematian tetapi juga karena perceraian, kehilangan pekerjaan, kehilangan harta benda atau putus cinta.

Dua macam dukacita atau kedukaan yang terjadi pada seseorang ada yang normal (uncomplicated grief) dan tidak normal (pathological grief). Kedukaan normal biasanya berlangsung pendek dan dapat diatasi dengan baik oleh penderitanya. Kedukaan normal disebut juga sebagai "uncomplicated grief."43 Kedukaan jenis ini sering melibatkan kesedihan, perasaan sakit, kesepian, marah, depresi, gangguan fisik dan perubahan dalam relasi dengan orang lain. Sebagaimana dikatakan oleh Gary R. Collins sebagai berikut : Normal grief often involves intense sorrow, pain, loneliness, anger, depression, physical symptoms and changes in interpersonal relations, all of which comprise a period of deprivation and transition that may last for as long as three years or more. ${ }^{4}$

Sebaliknya, kedukaan yang patologis (kedukaan normal yang berubah menjadi dukacita yang tak terselesaikan) biasanya berlangsung lama dan berlarut-larut. Penderita yang mengalami dukacita patogenik tidak mampu mengelola kedukaannya dengan baik sehingga kehidupannya terganggu. Tanda-tanda umum pathological grief antara lain : ${ }^{45}$

1. Keyakinan yang semakin kuat bahwa dirinya tidak berharga, suatu usaha yang menghukum diri sendiri.

2. Sikap tetap menghidupkan si orang yang sudah meninggal.

3. Tingkah laku anti sosial.

4. Kecenderungan menyengsarakan diri sendiri.

5. Sikap bermusuhan.

6. Rasa bersalah yang berlebihan.

7. Melarikan diri ke minuman keras dan obat-obatan yang berlarutlarut.

8. Menolak sama sekali kontak dengan orang lain.

\section{$\underline{\text { Tahap-tahap Kedukaan }}$}

Setiap individu memiliki cara yang unik dalam melewati masa-masa duka. Elisabeth Kubler-Ross membagi tahapan kedukaan ke dalam lima tanggapan emosi yang berbeda, yaitu:

43 G.L. Engel, "Is Grief a Disease? A Challenge for Medical Research in Christian CounselingBook by Gary R. Collins, 414.

44 Gary R. Collins, Christian Counseling:A Comprehensive Guide, (Texas: Word Books, 1982), 414.

45 E.P. Gintings, Konseling Pastoral TerhadapMasalahUmumKehidupan, (Bandung: Jurnal Info Media, 2009), 137. 
1. Denial and Isolation (Penyangkalan dan pengasingan). Penyangkalan merupakan satu indikasi adanya guncangan dalam diri seseorang. Kubler menjelaskan fungsi denial (penyangkalan) sebagai sebuah penahan terhadap berita yang mengguncangkan yang tidak diharapkan "Denial functions as a buffer after unexpected shocking news, allows the patient to collect himself and, with time, mobilize other, less radical defenses". ${ }^{46}$

2. Anger (Kemarahan): Pada tahap ini seseorang akan mengalami rasa marah, geram, iri hati atau benci. Dia bisa marah terhadap orang-orang disekelilingnya bahkan juga kepada Tuhan. Kubler menjelaskan di dalam bukunya "When the first stage of denial cannot be maintained any longer, it is replaced by feelings of anger, rage, envy and resentment". 47

3. Bargaining (tawar-menawar): Tawar-menawar merupakan usaha untuk menunda peristiwa yang pasti terjadi. Biasanya seseorang akan menyatakan janji-janjinya kepada Tuhan seandainya tawaran yang dia ajukan itu dikabulkan. Kubler menyatakan hal ini sebagai berikut "The bargaining is really an attempt to postpone; it has to include a prize offered "for good behavior", it also sets a self-imposed "deadline" (e.g., one more performance, the son's wedding), and it includes an implicit promise...". 48

4. Depression (depresi): Seseorang merasa tidak berhasil pada tahap pertama yaitu penyangkalan, demikian pula tahap kemarahan dan tawar-menawar. Akhirnya depresi mulai menyerangnya. Norman mencatat ada dua macam depresi, yaitu depresi reaktif (memikirkan kenangan-kenangan masa lalu) dan depresi persiapan (memikirkan kehilangan-kehilangan yang akan datang). Ini adalah saat dimana seseorang mengungkapkan kesedihannya yaitu dengan cara mengeluarkannya. ${ }^{49}$

5. Acceptence (penerimaan): Pada tahap ini seseorang mulai menerima kenyataan yang tak terelakkan itu. Dia juga bisa mengalami suatu keadaan kurang suka berbicara karena kehilangan minat terhadap hal-hal disekitarnya. Komunikasi non-verbal lebih berarti daripada komunikasi verbal pada tahap ini.

46 Elisabeth Kubler-Ross, On Death and Dying, (New York: Macmillan, 1969), 35

47 Elisabeth Kubler-Ross, On Death..., 44.

48 Elisabeth Kubler-Ross, On Death..., 73.

49 H. Norman Wright, Konseling Krisis: Membantu Orang Dalam Krisis dan Stress, (Malang: Gandum Mas, 1996), 173. 


\begin{abstract}
$\underline{\text { Akibat Kedukaan }}$
Berikut ini akan dibedakan akibat umum dan akibat khusus yang dimunculkan oleh kedukaan.

\section{a. Akibat Umum}

Beberapa akibat yang umumnya terjadi dalam diri orang yang berduka adalah menangis. Menangis merupakan ungkapan perasaan kesedihan yang mendalam (expresses deep feelings) dan untuk melepaskan ketegangan (release tension). ${ }^{50}$ Pengaruh lain yang muncul adalah gangguan tidur dan depresi. Selain itu juga diikuti oleh gangguan fisik seperti sakit kepala, lemas, napas pendek-pendek, kehilangan selera makan atau justru bertambah selera makannya.

Individu yang mengalami kedukaan juga dapat diserang kecemasan (anxiety), perasaan kosong (inner emptiness), rasa bersalah (guilty), kemarahan (anger), lekas marah (irritability), menarik diri dari orang lain (withdrawal from others), kelalaian (forgetfulness), penurunan ketertarikan terhadap seks (declining interest in sex), bermimpi tentang almarhum (dream about the deceased), mimpi buruk (nightmares), salah dalam penilaian (errors in judgement) dan perasaan kesunyian (feelings of loneliness). ${ }^{51}$
\end{abstract}

\title{
b. Akibat Khusus
}

Akibat khusus ini terjadi pada kedukaan yang bersifat patologis yaitu ketika kedukaan normal disangkal, ditunda dan disimpangkan. Hal ini terjadi pada kasus-kasus kematian mendadak atau tidak diharapkan, individu sangat bergantung pada almarhum, terjadi hubungan yang mendua hati (antara benci dan cinta), ada urusan-urusan yang belum terselesaikan antara yang berduka dengan almarhum (pertengkaran yang belum diselesaikan, kesalahpahaman atau kasih yang belum sempat dinyatakan). Penyebab lainnya bisa karena kematian yang tragis seperti kecelakaan, pembunuhan, atau bunuh diri. ${ }^{52}$

Gejala-gejala yang menyertai kedukaan patologis biasanya adalah social withdrawal (menyendiri dan tidak mau bertemu orang lain), minum minuman keras, cenderung menyengsarakan diri sendiri, sikap kasar dan bermusuhan bahkan sampai mencoba bunuh diri.

50 Gary R. Collins, Christian Counseling: A Comprehensive Guide, (Texas: Word Books, 1982), 417.

51 Gary R. Collins, Christian Counseling..., 417-418 (disadur).

52 Garry R. Collins, Christian Counseling..., 418 (terjemahan ). 


\section{Hakikat Makna Hidup}

Pada pokok bahasan ini, Penulis akan mengemukakan tentang pengertian makna hidup, sumber-sumber makna hidup, proses penemuan makna hidup, serta makna hidup dalam terang Alkitab.

\section{Pengertian Makna Hidup}

Makna hidup (the meaning of life) adalah hal-hal yang dianggap sangat penting dan berharga serta memberikan nilai khusus bagi seseorang, sehingga layak dijadikan tujuan dalam kehidupan (the purpose in life). ${ }^{53}$ Menurut Viktor E. Frankl yang dikutip oleh Lusiana, ${ }^{54}$ setiap kehidupan mempunyai makna dan kehidupan sendiri adalah suatu tugas yang harus dijalani. Dalam keadaan dan situasi apapun juga, makna hidup dapat ditemukan. Dalam berbagai keadaan bahkan keadaan yang sulit dan tidak menyenangkan sekalipun, makna hidup tetap dapat ditemukan. Penderitaan dan kepedihan, tidak dapat meniadakan makna hidup. Dalam peristiwa tragis pun, di situ makna hidup dapat dicari dan ditemukan. Seperti dalam keadaan sakit, bersalah, kematian dan bahkan perceraian sekalipun.

Viktor E. Frankl dalam bukunya mengutip kisah tentang Jerry Long yang diceritakan dalam majalah Texarkana Gazette demikian, "Jerry Long menderita kelumpuhan dari leher ke bawah (quadriplegic) akibat kecelakaan saat menyelam tiga tahun lalu. Dia berumur 17 tahun ketika kecelakaan terjadi. Sekarang dia menggunakan tongkat mulut untuk mengetik. Dia mengikuti dua kursus di Sekolah Kejuruan melalui sambungan telepon khusus. Dia juga mengisi waktunya dengan membaca, menonton televisi dan menulis. Jerry menulis kata-kata dalam sebuah surat kepada Frankl bahwa dia memandang hidupnya dengan penuh makna dan tujuan. Dia juga menuliskan "Leher saya memang patah tetapi itu tidak akan mematahkan hidup saya". ${ }^{55}$ Long telah melakukan upaya kreatif untuk mengubah situasi yang membuatnya menderita.

Setiap individu memiliki kemampuan untuk mengatasi suatu keadaan atau peristiwa yang menimpa kehidupannya. Kalaupun seseorang sudah berusaha namun tidak bisa mengatasinya dengan baik, maka sebenarnya ia memiliki kemampuan untuk tetap dapat bersikap dengan tepat. Jadi sekalipun seseorang tidak bisa mengubah suatu peristiwa atau keadaan yang

53 H.D. Bastaman, Logoterapi: Psikologi Untuk Menemukan Makna Hidup dan Meraih Hidup Bermakna, Jakarta: Raja Grafindo Persada, 2007, 45.

54 Lusiana S. \& Henny E.W., Penghayatan Makna Hidup Perempuan Bercerai, Jakarta: Jurnal Ilmiah Psikologi “ARKHE”, 2001, th. 6, No. 2, 47.

55 Viktor E. Frankl, Optimisme Di Tengah Tragedi-Analisis Logoterapi, Bandung:Nuansa, 2008, 224. 
menimpanya, namun ia bisa mengubah sikap dalam meresponi peristiwa yang terjadi. Viktor E. Frankl mengatakan bahwa cara manusia menerima nasibnya dan semua penderitaan yang terkait dengan nasib tersebut, cara dia memanggul bebannya, memberi dia cukup kesempatan-bahkan dalam situasi yang paling sulit sekalipun untuk memperdalam makna hidupnya. ${ }^{56}$

Seringkali situasi yang paling sulit dalam kehidupan seseorang justru memberi kesempatan kepadanya untuk mengembangkan kehidupan spiritualnya sehingga hidup jadi bermakna. Sebaliknya jika seseorang mengabaikan dan membenci kehidupannya maka hidupnya menjadi tidak bermakna.

Tentunya hidup bagi tiap orang memiliki makna yang berbeda-beda. Namun jika kita memperhatikan kisah Henokh dalam Alkitab, maka kita akan melihat bahwakehidupan Henokh tidak berakhir dalam kefanaan hidup atau kesia-siaan.Henokh tahu benar untuk apa dia hadir di dunia ini, dan itulah yang menentukan makna hidupnya yaitu hidup bergaul dengan Allah. ${ }^{57}$ Rick Warren dalam bukunya Purpose Driven Life mengatakan bahwa tanpa Allah, kehidupan tidak memiliki tujuan, dan tanpa tujuan, kehidupan tidak memiliki makna. Tanpa makna, kehidupan tidak memiliki arti atau harapan. ${ }^{58}$

Kita akan menemukan makna hidup jika kita bergaul dengan Allah Sang Pencipta. Dialah yang mengetahui untuk apa kita hidup, dengan siapa kita hidup dan berapa lama kita hidup.

\section{Proses Penemuan Makna Hidup}

Proses menemukan makna hidup adalah urutan pengalaman dan tahaptahap kegiatan seseorang dalam mengubah penghayatan hidup tak bermakna menjadi bermakna. ${ }^{59}$ Shellia mengutip pernyataan Bastaman tentang proses menemukan makna hidup ${ }^{60}$ adalah sebagai berikut:

Dalam kondisi tak bermakna (the meaningless life) sehubungan dengan peristiwa tragis tertentu yang dialami (tragic event), timbul kesadaran diri (self-insight) untuk mengubah kondisi tidak bermakna menjadi lebih baik lagi. Bersamaan dengan munculnya kesadaran diri, disadari pula adanya

56 Viktor E. Frankl, Optimisme Di Tengah Tragedi...,117.

57 Viktor E. Frankl, Optimisme Di Tengah Tragedi-Analisis Logoterapi, Bandung: Nuansa, 2008, 6

58 Rick Warren, Purpose Driven Life, (Malang: Gandum Mas, 2005), 32.

59 Shellia Regina dan Widya Risnawaty, Gambaran Makna Hidup Perempuan Dewasa Madya yang Bercerai Karena Perselingkuhan Suami, Jakarta: Jurnal Ilmiah Psikologi "ARKHE", 2007, vol. 6, No. 2,143

60 Ibid, 143 
nilai-nilai yang berharga atau hal-hal yang sangat penting dalam hidup (the meaning of life) yang kemudian ditetapkan sebagai tujuan hidup (the purpose in life). Hal-hal yang dianggap berharga dan penting ini, mungkin saja berupa nilai-nilai kreatif, nilai-nilai penghayatan, atau nilai-nilai bersikap. Atas dasar pemahaman diri dan pencarian makna hidup ini, timbul perubahan sikap (changing attitude) dalam menyikapi masalah. Dari kecenderungan berontak (fighting), melarikan diri (flighting), atau serba bingung dan tak berdaya (freezing), berubah menjadi kesediaan untuk lebih berani dan realistis dalam menghadapinya (facing). Kemudian pada umumnya semangat hidup dan gairah kerja meningkat, lalu secara sadar melakukan keikatan diri (self commitment) dalam melakukan berbagai kegiatan nyata yang lebih terarah (directed activities) demi memenuhi makna hidup yang ditemukan dan tujuan yang telah ditetapkan (fulfilling meaning and purpose of life). Bila tahap ini bisa dilalui, maka akan melahirkan perubahan kondisi hidup yang lebih baik dan mengembangkan penghayatan hidup bermakna (the meaningful life) dengan kebahagiaan (happiness) sebagai hasil sampingannya.

Namun pada kenyataannya, tiap orang berbeda satu dengan yang lainnya dalam menjalani proses menemukan makna hidup karena situasi dan kondisi yang tidak sama. Dengan demikian tahapan demi tahapan yang harus dilalui pun tentu akan berlainan.

\section{Makna Hidup dalam Terang Alkitab}

Makna hidup merupakan suatu kebutuhan normal, suatu bagian yang terkandung di dalam diri manusia sebagai makhluk pribadi, suatu kebutuhan yang hanya dapat dipenuhi oleh Allah sendiri, dan suatu kebutuhan yang ingin dipenuhi Allah. ${ }^{61}$

Dalam iman Kristen kita percaya bahwa Firman Tuhan berkuasa dan sanggup untuk memberikan jalan keluar ketika kecemasan akibat peristiwa tragis yang tidak dapat terelakkan hadir dalam hidup ini. Roma 8:28 mengajarkan kepada kita bahwa Allah turut bekerja dalam segala sesuatu yang terjadi dalam kehidupan kita. Dari ayat ini kita tahu bahwa Allah turut bekerja dalam segala sesuatu baik itu melalui pengalaman yang mengesankan atau bahkan penderitaan.

Dalam detik-detik akhir hidup Paulus, ia berkata "Aku telah mengakhiri pertandingan dengan baik, aku telah memelihara iman dan sekarang aku akan menerima mahkota kehidupan". Sasaran akhir hidup yang

61 Larry Crabb, Konseling yang Efektif dan Alkitabiah, Bandung:Yayasan Kalam Hidup, 1995, 71 
ingin dicapai seperti apa, akan menjadi panduan bagaimana kita mengisi hidup kita sekarang ini. Kita juga dapat melihat tujuan akhir dari Rasul Paulus dalam Filipi 3:14 adalah memperoleh hadiah yaitu panggilan sorgawi dari Allah dalam Kristus Yesus. Dengan berpedoman pada sasaran atau tujuan akhir hidup yang ingin dicapai, pastilah kita akan mengisi hidup yang Tuhan berikan ini dengan sesuatu yang bermakna. Hidup bukan datangnya yang penting, tetapi perginya. ${ }^{62}$ Oleh sebab itulah, kita harus mengisi kehidupan ini dengan sesuatu yang bermakna dan yang bernilai kekal.

Hal-hal tersebut dapat menjadi sumber makna hidup sejati apabila kita tahu dengan benar dimana meletakkannya. Jika kita meletakkan makna hidup kita pada apa yang tampak dan tidak pasti, maka makna hidup yang sejati akan sulit ditemukan. Namun jika kita meletakkan makna hidup kita pada Allah yang menjadi satu-satunya sumber kepastian dan tidak pernah berubah, maka hidup kita akan bermakna sekalipun dalam penderitaan yang berat.

Paulus dalam Filipi 3:5-6 mengatakan "Tetapi apa yang dulu kuanggap keuntungan bagiku sekarang kuanggap rugi karena pengenalan akan Yesus Kristus, Tuhanku, lebih mulia dari semuanya itu. Oleh karena Dialah aku telah melepaskan semuanya itu dan menganggapnya sampah supaya aku memperoleh Kristus.” Jadi apa yang dulu kita anggap bermakna bisa menjadi tidak bermakna lagi karena kita sudah menemukan makna yang sesungguhnya atau sejati di dalam Kristus. Ketika makna hidup yang sejati ini sudah dipegang seseorang, maka dia akan sanggup untuk bertahan dalam penderitaan atau kedukaan macam apapun. Inti dari semuanya adalah memiliki pengenalan yang benar akan Yesus Kristus Tuhan kita. Inilah makna hidup yang sesungguhnya

\section{Pelayanan Pastoral danMaknaHidup}

Tugas dalam pelayanan pastoral antara lain melayani manusia yang berusaha untuk memperoleh makna dalam hidupnya. Pelayanan ini dilakukan berdasarkan iman kepada Yesus Kristus dalam arti bahwa dari Yesus Kristus kita tahu apa itu percaya. Dari Dia kita belajar apa itu harapan dan berharap. Dan Ia sendiri memperlihatkan kepada kita dalam hidup-Nya apa itu kasih dan mengasihi. ${ }^{63}$ Dengan demikian, doa, harapan, percaya, dan kasih menempati tempat yang sentral dalam pelayanan pastoral. Ini adalah hal-hal yang kita lakukan supaya kita dapat berfungsi sebagai manusia di dalam dunia.

Melalui pelayanan pastoral, anggota jemaat dapat dibantu untuk mengungkapkan apa yang menjadi permasalahan hidupnya atau hal-hal yang

62 Buletin : Shinning Star, Tahun V/No. 50/Edisi Juli 2013, hal. 11-12

63 J.L. Ch. Abineno, Pedoman Praktis Pelayanan Pastoral,......101 
mengganggu kehidupannya sehingga tidak berjalan dengan stabil. Percakapan pastoral bisa menjadi salah satu jembatan yang membantu jemaat untuk mencerna perasaan atau emosi negatif yang muncul dalam dirinya. Setelah dicerna dengan baik, anggota jemaat dibantu untuk menyadari kenyataan pahit yang menimpanya dan berpikir realistis kemudian belajar untuk hidup dalam situasi yang baru secara perlahan-lahan. Prinsip yang harus diingat adalah tidak melakukan pelayanan pastoral ini dengan paksaan atau tekanan karena dapat menimbulkan dampak yang makin kompleks dalam diri jemaat yang dilayani.

Berhubung pelayanan pastoral ini merupakan suatu proses yang memerlukan waktu dan aktivitas maka penemuan makna hidup dalam kehidupan jemaat yang dilayani juga tidak bisa terjadi secara instan. Haruslah diingat bahwa penemuan makna dan tujuan dalam diri tiap orang unik dan berbeda. Seseorang memerlukan waktu hingga akhirnya dia bisa sampai pada tahap menerima kenyataan yang terjadi kemudian memulai suatu kehidupan baru yang penuh arti dan tujuan. Dalam hal ini, seorang pelayan Tuhan harus membantu jemaat mengerti apa yang hendak dicapai dan ke mana arah hidupnya ke depan. Seseorang yang mengalami peristiwa tragis dalam kehidupannya seringkali sulit untuk berpikir jernih sehingga diperlukan bantuan untuk itu. Disinilah peran pelayanan pastoral menjadi sangat penting dan dibutuhkan sehingga jemaat bisa tertangani dengan baik dan menemukan makna dari setiap peristiwa dalam kehidupannya.

\section{KESIMPULAN}

Pelayananpastoral merupakan pelayanan penggembalaan dan pendampingan kepada jemaat yang didalamnya ada kegiatan kemitraan, bahumembahu, menemani, dan berbagi dengan tujuan saling menumbuhkan, menguatkan dan mendukung. Demikian halnya pelayanan pastoral kepada orang yang berduka seharusnya berisikan kegiatan-kegiatan di atas. Melalui kegiatan bahu-membahu, menemani atau berbagi tersebut, diharapkan jemaat yang berduka dapat bertumbuh secara rohani. Dengan pertumbuhan rohani yang baik, jemaat yang berduka diharapkan bisa menemukan arti hidup melalui penderitaan atau krisis yang sedang dihadapinya.

Hal itu bisa dicapai bukan hanya melalui kunjungan pada saat ibadah penghiburan saja, tetapi bisa melalui percakapan pastoral dan kunjungan yang rutin. Percakapan pastoral meski singkat atau biasa namun bila dikerjakan dalam kesungguhan dan ketulusan, akan membantu jemaat yang berduka untuk mengungkapkan persoalan-persoalan yang muncul akibat kehilangan yang dideritanya. Para pelayan Tuhan dapat melihat fakta-fakta yang dialami dan 
dihadapi jemaatnya yang berduka sehingga bisa memberikan pertolongan yang tepat sasaran. Kunjungan rutin dapat menguatkan dan menghibur jemaat sehingga tidak merasa sendiri. Selain itu dalam kunjungan rutin juga bisa dilakukan percakapan pastoral yang mendalam.

Pola pelayanan pastoral dengan cara memberikan bantuan praktis berkaitan dengan persiapan penguburan, pelayanan doa dan pemberitaan Firman di kebaktian penghiburan dan pemakaman tidaklah salah hanya saja kurang efektif. Pola pelayanan seperti ini kurang bisa menyentuh dan menyelesaikan perasaan-perasaan problematis akibat kedukaan.

Berdasarkan penelitian Penulis, adanya ketidakefektifan pelayanan pastoral dapat terjadi karena kurangnya pemahaman tentang hakekat pelayanan pastoral di antara pelayan Tuhan. Berhubung kurangnya pemahaman tersebut maka mereka tidak memprioritaskan waktu untuk melakukan bentuk pelayanan pastoral yang lain (seperti kunjungan, telepon dan percakapan pastoral), ditambah lagi dengan banyaknya kegiatan gerejawi yang menyita banyak waktu. Bila kendala ini tidak dicarikan jalan keluarnya atau diselesaikan, maka pelayanan pastoral akan sulit untuk menyentuh kehidupan pribadi jemaat. 


\section{DAFTAR PUSTAKA}

Abineno, J.L. Ch.

1991

Pelayanan Pastoral Kepada Orang Yang Berduka, Jakarta: BPK Gunung Mulia

1993 Pedoman Praktis Untuk Pelayanan Pastoral, Jakarta: BPK Gunung Mulia

Adnan, S. Ricardi 2006

Potret Suram Bangsaku-Gugatan dan Alternatif Desain Pembangunan, Depok: FISIP-UI Press

Alwi, Hasan

2001

Kamus Besar Bahasa Indonesia, Jakarta: Pusat Pendidikan Nasional

Balz, H.

1991

Exegetical Dictionary of the New Testament, Vol. 3,Michigan: Wm. B. Eerdmans Publishing Company

Bastaman,H.D. 2007

Logoterapi: Psikologi Untuk Menemukan Makna Hidup dan Meraih Hidup Bermakna, Jakarta: Raja Grafindo Persada

Beek, Van Aart 2007

Pendampingan Pastoral, Jakarta: BPK Gumung Mulia

Clinebell, Howard J.

1984

Basic Types of Pastoral Care and Counselling-Resources for the Ministry of Healing \& Growth, London: SCM Press Ltd.

2002 Tipe-tipe Pendampingan dan Konseling Pastoral, Yogyakarta: Kanisius.

Collins, Gary R. 1972

Effective Counseling, Illinois: Published by Creation House.

1982 Christian Counseling: A Comprehensive Guide, Texas: Word Books 
Frankl, E. Viktor, 2008

Optimisme di Tengah Tragedi: Analisis Logoterapi, Bandung: Penerbit Nuansa

Gintings, E.P. 2009 Konseling Pastoral Terhadap Masalah Umum Kehidupan, Bandung: Jurnal Info Media

Graham, Billy

(ny)

Buku Pegangan Pelayanan, Jakarta: Persekutuan Pembaca Alkitab

Guralnik, David B. 1967

Webster's New World Dictionary, California: California State Department of Education

Hartley, John E. 1997

Dictionary of Old Testament, Vol. 2, Michigan: Zondervan Publishing House

Henny \& Lusiana, 2001

Penghayatan Makna Hidup Perempuan Bercerai, Jakarta: Jurnal Ilmiah Psikologi "ARKHE”

Hurlock, Elizabeth B 1980

Psikologi Perkembangan Suatu Pendekatan Sepanjang Rentang Kehidupan, Jakarta: Erlangga

Kubler-Ross, Elisabeth 1969 On Death and Dying, New York: Macmillan

Lartey, Y. Emmanuel 2003

In Living Color-An Intercultural Approach to Pastoral Care and Counseling, London: Jessica Kingsley Publishers

McComiskey, Thomas 1979

Dictionary of New Testament Theology Vol. 2, Michigan: Zondervan Publishing House 
Moleong, J. Lexy

2006

Metodologi Penelitian Kualitatif, Bandung:PT. Remaja

Rosdakarya

Nixon,Rosemary

1997

Dictionary of Old Testament and Exegesis Vol. 2,

Michigan: Zondervan Publishing House

Patton, John

1990

From Ministry to Theology-Pastoral Action andReflection (Nashville:Abingdon Press)

RiantNugroho D. \& Tri Hanurita S.

2005 Tantangan Indonesia Solusi Pembangunan Politik Negara

Berkembang, Jakarta: Penerbit PT. Elex Media

Komputindo

Sahardjo,Hadi P.

2006 Konseling Krisis dan Terapi Singkat, Bandung: Pioner Jaya

Susanto, Daniel

2006 Pelayanan Pastoral di Indonesia pada Masa Transisi, Jakarta: STT Jakarta

2008 Sekilas tentang Pelayanan Pastoral di Indonesia Jakarta:

Majelis Jemaat GKI Menteng

Tumanan, Perdian K.M

2005 Menemukan Makna Di Dalam Siklus Kehidupan, Disciples: Buletin BPC Perkantas Jatim Edisi JanuariFebruari

Warren, Rick

2005 Purpose Driven Life, Malang: Gandum Mas

Westberg, Granger

1962 Good Grief, Philadelphia: Fortress

Wiryasaputra, Totok S.

2003 Mengapa Berduka, Yogyakarta: Penerbit Kanisius 